Article

\title{
Generosity and Environmental Protection: How Strong Is the Relationship between Giving and Sustainability?
}

\author{
Adela Lazăr ${ }^{\dagger}$, Ioana Sîrbu ${ }^{\dagger}\left(\mathbb{0}\right.$, Karla Barth $^{\dagger}$, Claudia Bacter $^{*}+{ }^{+}$and Adrian Hatos ${ }^{\dagger}$ \\ Faculty of Socio-Humanistic Science, University of Oradea, 410610 Oradea, Romania; \\ adela.lazar11@gmail.com (A.L.); ioana.uoradea@gmail.com (I.S.); karla_barth@yahoo.com (K.B.); \\ ahatos@uoradea.ro (A.H.) \\ * Correspondence: claudianbacter@gmail.com \\ + These authors contributed equally to this work.
}

Citation: Lazăr, A.; Sîrbu, I.; Barth, K.; Bacter, C.; Hatos, A. Generosity and Environmental Protection: How Strong Is the Relationship between Giving and Sustainability? Sustainability 2022, 14, 869. https:// doi.org/10.3390/su14020869

Academic Editor: Jordi Colomer Feliu

Received: 11 November 2021

Accepted: 11 January 2022

Published: 13 January 2022

Publisher's Note: MDPI stays neutral with regard to jurisdictional claims in published maps and institutional affiliations.

Copyright: (c) 2022 by the authors. Licensee MDPI, Basel, Switzerland. This article is an open access article distributed under the terms and conditions of the Creative Commons Attribution (CC BY) license (https:// creativecommons.org/licenses/by/ $4.0 /)$.

\begin{abstract}
Background: Sustainability is a crucial priority and a critical part of the modern world. Promoting pro-social values to the younger generation is an issue addressed throughout this paper. The present study aims to answer the question of whether generosity, as a positive attitude towards others, and sustainability, as a positive attitude towards the environment, are related. (2) Methods: The current research includes a sample of 4333 adolescents, ages 14 and 15, who attend schools in Bihor County, Romania. (3) Results: The regression analysis indicates a significant correlation between sustainable values, operationalized through adolescent involvement in environmental organisations, and generosity. (4) Conclusions: Sustainable behaviour can be considered a form of giving that contributes to the collective good. Our research outlines a significant need for a new set of competencies provided through a newly designed curriculum and/or through focused training, in order to cultivate generosity across cultures, ecologies, and generations; at the same time, we also highlight the significant role that the joint efforts of the school-family-library trifecta in supporting this goal.
\end{abstract}

Keywords: sustainability; generosity; values; education; civic virtue

\section{Introduction}

Worldwide, through the aid of education, more and more focus is being placed on fostering the requisite values and attitudes towards a "sustainable future" [1]. The concept of sustainability, at its most fundamental level, relates to a system's ability to function endlessly. When related to society, the basic understanding of this concept is that of achieving a balance between the use of natural, economic, and social resources in order for societies to receive the goods and services that they require, while also promoting the conservation of resources rather than their depletion [2].

Concerning the above mentioned concept, the aim of this paper was to investigate sustainable values and their relation to generosity. We also addressed the educational values of the younger generation, given the dynamic context and challenges of today's society. One of these values is generosity. In order to give the world what it now needs, it is essential to contribute to the raising of awareness and cultivating of values with regard to sustainability by educating children accordingly, starting from an early age. In this way, we can ensure the needed human resources for a sustainable future.

\subsection{Educating Children about Human Values and Sustainability}

Education, as a system and as a process, aims to design harmonious personalities of the educated, both as bearers of common axiological contents and as generators of societal values.

The hierarchy of values is actualized in a postmodern society, where, in the context of new cultural dynamics such as globalism, localism, interculturality and multiculturality, 
a new direction of educational values is emerging. Thus, the general values of Good, Truth, Utility, Beauty, and Health are reflected by new concerns such as technological progress, usefulness of applied sciences, economic management, care and concern for the environment in which we live, healthy nutrition, etc., together with generosity and sustainability [3].

In order to develop sustainability, education must transmit the component of active awareness, measured as a product of caring attitudes towards the environment and towards people and manifested through concrete actions of involvement, including civic and social participation.

Based on Brown [4], we understand that the essential component of generosity is the act of kindness, by which we freely and abundantly give what is necessary to the beneficiary. In a similar manner, Diamond [5] approaches the human-nature relationship as mutual, but subscribes to it in the form of a social contract of reciprocal exchange through which humans must repay the respect due to nature by giving back, based on a social contract whereby the human relationship with nature is extrapolated to a shared ecological social capital.

"Sustainability is commonly treated as an ethical notion that helps us to decide on proper rules for sharing (environmental and natural) resources with future generations" [6], by ensuring that "the present needs are met while not compromising the ability of future generations to meet their own needs" [7].

Interest in the role that education plays in sustainable development has increased in recent decades, and the framework documents formulate common global goals in promoting this specific issue, but the importance of education and the moral dimensions of learning from an early age have been less considered [8]. Education for Sustainable Development (ESD), as defined by UNESCO, enables every human being to acquire the knowledge, skills, attitudes and values needed to create a sustainable future [9].

Values, defined as abstract concepts of what society considers to be good, fair and worthy, reflect aspects of cultural identity [10]. We are aware that values, as moral-affective constructs, are established on the basis of three components: a cognitive component (knowledge, beliefs, reasoning, judgements), an affective component (feelings, motivations) and a behavioural component (actions, habits). It is known that complex values are learned during adolescence [11,12], but their foundations must be built from an early age, with the family being the first and perhaps the most important moral agent in a child's life. The power of example unquestionably remains the most effective resource that the family can employ in shaping the child's moral profile, wherein school extends the process of modelling through various educational contexts.

School, alongside family, as an agent of moral development, aims to build a framework suitable for the internalization of moral components in the structure of the educated personality in relation to the prescribed goals of education. The paramount focus of this educational area is to shape the child's moral profile [13] by educating moral convictions and by instilling moral conduct.

In enabling children to internalize the values related to the environment, it is important to provide them with learning opportunities that empower them to collect information, to develop skills and to identify effective ways of addressing environmental issues. Therefore, education in this area becomes an ongoing, interdisciplinary and multi-disciplinary learning process, wherein children, alongside teachers, parents and other community members, cooperate in order to deal with environmental challenges, given that they share the same values, the same mindset and the same ethics [14,15].

The issue of sustainable development involves moral values; educational institutions are instrumental in promoting these values [8]. Therefore, the moral dimension-reflected through moral values education-is a key element in achieving sustainable development, while early education can set the breeding ground for cultivating these values.

Based on the model of Uitto et al. [16], we embraced the fact that schools' sustainability education should provide not only ecological experiences, but more importantly, school 
should connect pro-social and agency experiences through an approach that emphasizes pro-environmental values and self-efficacy for general ecological behaviour.

In such a setting, education would ideally strive to create a unity between these values and the bio-psycho-socio-cultural needs of each human personality. We are thus interested in the discussion of moral education as the promotion of the value of Good and Care (for oneself, for others and for the world), the formulation of which is a particular, specific content of axiological education as an umbrella concept.

\subsection{Education and Civic-Mindedness}

Education has an important responsibility in assisting future adult citizens to be moral, as well as also caring, generous and respectful individuals, especially in the early formative childhood [17].

The undertaken responsibility in this setting lies within both the formal and informal education that takes place within the family. Children must be encouraged and taught from an early age about values and also supported in developing the right moral and civic attitudes. These can be achieved by civic education, which aims to train "wellinformed citizens who are also caring, responsible and engaged, and possess critical thinking skills" [18]. Therefore, promoting active citizenship must encourage them to get involved in democratic bodies, in political proposals, in the implementation of local, national and regional policies, beyond charity and volunteering. In trying to guide civic education towards this direction, the borders of formal learning are being crossed; therefore, other actors in society have an educational stake: "how people practice their citizenship shapes what they learn: there is a 'hidden curriculum' in society at large, as well as in the school" [19].

Stakeholders in civil society, in which youth can practice civic values, are advocacy groups, institutions (religious, academic) and non-governmental organisations [20]. "Civil society is composed of a plurality of actors, ranging from environmental NGOs, epistemic communities and social movements to civil society organizations" [21]. Civil society's roles vary from collecting data and disseminating information, to counselling and support, to policy drafting, to implementation, to environmental management and governance, to advocacy [20]. In most cases, civil society and local communities implement environmental policies that promote sustainable development [22]. The participation of civil society in achieving the Sustainable Development Goals (SDGs) (2030 Agenda) is widely acknowledged, given the stakeholders' role in the community, their contribution with regard to the identifying of needs, in the setting of priorities, in developing and implementing policies, and also in enabling the engagement of all actors in order to fully participate in this process [23]. This valuable cooperation between civil society actors and governments, and their involvement in the policymaking process, are key elements that ensure a "good environmental governance" [24].

One key solution to the challenges of today's world relies on the human resource, provided by today's youth as the opinion leaders and decision makers of the future.

The common UN Sustainable Development Policy agenda comprises the joint efforts, through strategic programs, promoted at different community levels. It is through activating a global Education for Sustainable Development partnership that we can bring cross-sector stakeholders together in order to share knowledge, technology and resources, to shape good practices and bring numerous positive impacts.

The Sustainable Development Goals (SDGs), internationally agreed upon in 2015, represent the objectives of governmental policies that are proposed for the development of a global agenda for development that is both equitable and sustainable, in social, economic and environmental terms. This is aimed at investments in healthcare and educational services, crucial to children's development, to fulfil children's potential and enable them to later contribute to society. The achievement of these targets helps to secure the future for generations to come [25]. 
In this context, we point to several programs and interventions mentioned in the UN Youth Strategy (UNEP), which seeks to engage 1.8 billion young people in driving global efforts to promote a peaceful, equitable and sustainable world. Kids' Corner is a digital classroom that gathers more than 50,000 young people from across Australia, the US, the UK and China, aiming to impact one million young people worldwide by the end of 2022. Another major project is the UK-based Wastebuster, which promotes environmental messages throughout its campaigns. Such examples include the Clean Seas Campaign, Beat Pollution, UN Decade of Ecosystem Restoration, Wild for Life and others. This partnership will roll out the campaign in 76 countries, representing a combined network of over 250,000 schools and 56 million young people worldwide. The United Nations Environment Programme hosts the Sustainable United Nations facility in Geneva, which supports UN organisations towards tackling climate neutrality and environmental sustainability. Greening the Blue is another initiative promoted by the United Nations Sustainable Development Facility, which shares best practices and sustainability initiatives within the UN through communication activities [26].

\subsection{Generosity and Correlates of Generosity}

When it comes to generosity, the motivations for giving and the amount given are influenced by the availability of economic and social resources. Distinct degrees of resource availability are represented by varied "circles of generosity" radiating at different distances [27]. Safra et al. [28] show that from an early age (6-7 years), children from higher socio-economic backgrounds are significantly more generous than those from poorer backgrounds. When it comes to the level of education of parents, it seems that the number of years of schooling is positively correlated with the amount of donations and volunteering. This is in addition to the greater amount of resources available to a family from a higher socioeconomic class. This could be explained in part by the fact that education facilitates the development of higher levels of empathy, better communication skills and improved problem-solving abilities [29-31]. On the other hand, self-interested motives can often lie behind generosity: the desire for a positive image in society, reputation and avoidance of guilt [27,32,33]. For example, it has been found that rich people who are generous, as opposed to those who are not generous, are perceived as deserving to be rich, having acquired wealth with difficulty, generally attributing wealth to internal factors [34].

Studies conducted in an attempt to understand why some individuals help more than others reveal significant gender differences, with girls generally being more generous than boys [33,35-38]. Women are more generous than men because of a greater awareness of the costs of generous behaviour. Thus, women are more generous than men when the total monetary cost of generosity is low [39]. Empathy is also more present among women than men and seems to be an important factor in explaining the gender gap [40]. However, there are also studies showing that when indicators of social and human capital (level of schooling, hours of work, economic level, education, religiosity, etc.) are controlled for, gender gaps are smaller [41].

In addition, people attending religious services are more likely to give due to the influence of leaders in their religious congregations calling upon them to do so [27]. Religiosity is strongly correlated to high degrees of generosity and helping in general, with volunteering work being done not just for those in one's own church [42-45].

Previous research has addressed the link between generosity and ecological/ecofriendly attitudes towards the environment [46-50], and some claim that environmental attitudes can even be considered as a form of generosity [27].

Stern and Dietz [50] note that preoccupation with/for the environment is linked to egoistic, social-altruistic, and biospheric values. In more current research, Stern's [49] opinion is that the most powerfully implicated values in the activation of personal promedium norms are altruistic or auto-transcendent values.

Ideas in favour of helping motivate people to act in favour of the environment are often based on the costs or advantages to a human group, such as a community, ethnic 
group, nation-state or humanity as a whole [47]. It seems that there is no distinction in the public consciousness between valuing nature for its own sake and valuing nature for the benefits it provides to people. The authors believe that the values that support pro-social behaviours are remarkably similar to those that drive pro-environmental behaviour. Only the "recipient" differs between these two categories: other humans in one example, or all living organisms and non-living nature in the other.

The authors of a recent study found that members of pro-environment organisations are more likely to help other members than non-members. Otto et al. [51] consider that pro-environmental activities are driven by generalized pro-social willingness and (partially) explained by domain connectivity.

Previous research suggests that there is a correlation between generosity and the sustainable attitudes of children and youth. One study, investigating three attitudes about money that adolescents are likely to internalize-frugality, materialism and generosityrevealed that subjects who score low on frugality or generosity, or high on materialism, are unlikely to engage in environmentally friendly behaviours, since these economic attitudes play at least some role in such activities [46]. Connections have also been identified between literacy, science, arts and civic skills of generosity, as well as ecological practices of generosity engaging children, school staff and community policy makers.

Within the new context brought by contemporary shortcomings, the concern for the environment and for all living beings, expressed by the overall sustainable attitude, may represent one of the correlates of generosity, although it may also exist in the absence of the condition of "giving" similar to the self-sufficiency variable observed by Herzog and Price [27]. To explain this premise, we recall the main purpose of sustainability, which is to protect and to ensure a secure future in which passive (preventive and consumptionminimizing) behaviours are as important as active action. Recognizing self-sufficiency among the correlates of generosity is similar to considering a reduced ecological footprint as a form of giving, in the sense that reducing the use of resources constitutes a gift of the giver. The above-mentioned authors (who put forward this meaning) indicate that we should not limit the understanding of generosity to the giving of resources, which can only be done from advantageous positions, but also to include the reservation of resources from depletion as a form of giving towards the environment and towards the planet (here, by giving we mean generosity). Furthermore, the socio-relational settings may also have an impact, by being more or less conducive to giving, along with the perceptions of self-giving as compared to others' participation [27].

Sustainable global generosity is becoming an increasingly important practice for future generations, who will face even greater environmental dilemmas. In this regard, according to Liu [52], ecological generosity expressed in civic conduct is a key competence for our global future, being a competence that must be taught to youth, in civic and cultural institutions, particularly in primary schools. The author extends the meaning of the concept of generosity to the sum of people's proactive behaviours and attitudes over time, stipulating that the civic expressions of generosity depend on the cultivation of generosity practices across time and cultures.

The issue of generosity is expanded by Herzog and Price [27] into a broader conceptualization that preserves and combines the different types into nine specific forms of generosity, all of which are given freely to enhance the well-being of others. Among these, we recall the following correlations, relevant for our study: sustainability giving, the contribution of efforts towards environmental resources, volunteering, and giving time and services for charitable causes. Another common form of generosity is assigned as political activity: giving time to engage in political action or to become civically invested in charitable causes.

Based on the literature, this study aims to answer the questions of whether and in what measures generosity — as a positive attitude towards others—and sustainability —as a positive attitude towards the environment are related in the case of adolescents.

Starting from the main underlying concern, our research objectives are as follows: 
1. To investigate the level of involvement of adolescents in civic (cultural, political) and environmental activities.

2. To investigate the relationship between generosity and adolescent involvement in civic (cultural and political) activities.

3. To investigate the relationship between generosity and sustainable values.

Building on the results of previous studies and our observation the present study puts to test three main hypotheses:

Students who are more involved in cultural activities will engage in generous acts more than those who are not part of such NGOs.

Students involved in political organisations will have a more generous attitude towards others.

Students who are more concerned about the environment and are more involved in environmental NGOs will also engage in more acts of generosity than non-members.

\section{Materials and Methods}

\subsection{Sample}

The present research was conducted using data from the "Educational Monitor of Practice and Attitude Outcomes in Schools in Western Romania" (MERPAS). This crosssectional study was conducted by the University of Oradea, represented by the Doctoral School of Sociology in partnership with the Bihor County Centre for Educational Resources and Assistance (CJRAE) and the Bihor County School Inspectorate. The data refer to students who were in the 8th grade in the 2018-1019 school year. The entire population of 8th grade students attending schools in Bihor County, aged 14/15 years, was considered. The initial sample consisted of 4708 participants, from which invalid responses were removed, thus resulting in 4333 valid responses. The final analysed sample included approximately equal numbers of girls and boys.

\subsection{Variables and Operationalization}

The dependent variable is adolescents' self-reported level of generosity, operationalized by their individual score on the Generosity Rating Scale [48]. The scale was constructed in large sample studies and repeatedly shows good psychometric properties (unidimensionality, Cronbach's Alpha greater than 0.7). An important point to note is that it measures generosity as an attitude, as an adolescent's willingness to help, and not the behaviour itself. The generosity scale was developed by Hatos [53], starting from the conceptualization of generosity and the scale developed by [46], which defines generosity referring to people's willingness to share their money and possessions to help other people. Based on this conceptualization, the operationalization of generosity is carried out on the basis of adolescents' responses and not on the basis of behaviours; this type of scale is appropriate for large samples, as is the case of the current study. The 6 items of the scale offer the possibility of a Likert-type response, with 4 response variants (ranging from "I like it a lot" to "I like it very little"). The scale was tested in two large samples of 8th grade students (14 and 15 years old). Thus, its psychometric properties were analysed in 2011 on a sample of 4451 adolescents and in 2019 on a sample of 4333 adolescents. Confirmatory factor analyses showed the unidimensionality of the 6 items, and in both cases the Cronbach alpha index of the generosity scale had values greater than 0.7 . In addition, the factor loadings of the items for both samples analysed are relatively homogeneous.

The confirmatory factor analyses highlight the good psychometric features of the 6 item Generosity scale (Cronbach's Alpha $=0.830, \mathrm{KMO}=0.860)$. Analysing Table 1 , we can see that a large proportion of adolescents report that they help people in need and that this usually makes them feel good. On the other hand, we observe that when it comes to sharing goods, making donations or choosing a job that involves helping others, quite a few teenagers (compared to the other items) find that the statement does not fit them or fits them to a small extent. 
Table 1. Descriptive statistics: Dependent variable—generosity.

\begin{tabular}{|c|c|c|c|c|c|c|}
\hline \multicolumn{7}{|c|}{ Generosity-Scale Variable, Factor Score of 6 Attitude Items Scored from 1 to 4} \\
\hline & $\begin{array}{l}\text { It Fits Me to a } \\
\text { Great Extent }\end{array}$ & $\begin{array}{l}\text { It Fits Me in a } \\
\text { Certain Way }\end{array}$ & $\begin{array}{c}\text { It Fits Me a } \\
\text { Little }\end{array}$ & $\begin{array}{l}\text { It Fits Me Very } \\
\text { Little }\end{array}$ & $\begin{array}{l}\text { I Don't Know } \\
\text { and Missing }\end{array}$ & $\begin{array}{l}\text { Valid } \\
\text { Cases }\end{array}$ \\
\hline $\begin{array}{c}\text { I usually help those } \\
\text { who truly } \\
\text { need support }\end{array}$ & $45.3 \%$ & $33.2 \%$ & $8.3 \%$ & $2.8 \%$ & $\begin{array}{l}10.1 \% \\
0.3 \%\end{array}$ & 3884 \\
\hline $\begin{array}{l}\text { When someone asks } \\
\text { for help, I do not } \\
\text { think twice }\end{array}$ & $42.9 \%$ & $35.7 \%$ & $9.3 \%$ & $2.4 \%$ & $\begin{array}{l}9.3 \% \\
0.4 \%\end{array}$ & 3913 \\
\hline $\begin{array}{c}\text { Helping someone } \\
\text { who is poor makes me } \\
\text { feel good }\end{array}$ & $59.7 \%$ & $22.2 \%$ & $6.1 \%$ & $2.6 \%$ & $\begin{array}{c}9 \% \\
0.4 \%\end{array}$ & 3926 \\
\hline $\begin{array}{l}\text { I like sharing goods } \\
\text { with other people }\end{array}$ & $35.2 \%$ & $32.3 \%$ & $14.6 \%$ & $7.7 \%$ & $\begin{array}{l}9.7 \% \\
0.5 \%\end{array}$ & 3892 \\
\hline $\begin{array}{c}\text { I like making } \\
\text { donations for people } \\
\text { in need }\end{array}$ & $34.5 \%$ & $28.5 \%$ & $15.1 \%$ & $7.6 \%$ & $\begin{array}{c}13.9 \% \\
0.4 \%\end{array}$ & 3713 \\
\hline $\begin{array}{l}\text { I would like to have a } \\
\text { job where I could } \\
\text { help as many people } \\
\text { as possible }\end{array}$ & $37.9 \%$ & $25.3 \%$ & $13 \%$ & $8.2 \%$ & $\begin{array}{l}15 \% \\
0.6 \%\end{array}$ & 3658 \\
\hline
\end{tabular}

Regarding the control variables, 3 variables were included. In previous research [37], these variables, using the same population, were found to have a significant effect. Thus, we introduced as control variables the following: gender, socio-economic status (proxy variables: mother's level of education and family economic status) and the declared level of religiosity. Since the data showed a strong correlation between the mother's educational level and the father's educational level, in order to avoid multicollinearity, only the mother's educational level was included in the multivariate models.

The independent variables referred to involvement in cultural life, involvement in politics and involvement in environmental organisations. Each of the 3 independent variables are operationalized by using the students' responses to the question of whether they are part of organisations, with the 3 objectives mentioned above.

The involvement of Romanian teenagers in voluntary organisations, in general, is very low [54]. Regarding our sample, out of a total of 4333 respondents, only $8 \%$ said that they belong to a voluntary organisation (see Table 2).

Table 2. Non-governmental organisation membership.

\begin{tabular}{ccc}
\hline $\begin{array}{c}\text { Are You a Member of a Non-Governmental Organisation } \\
\text { (Association, Foundation)? }\end{array}$ & Frequency & Percent \\
\hline Yes & 345 & 8.0 \\
\hline No & 3328 & 76.8 \\
\hline I don't know & 632 & 14.6 \\
\hline Total & 4305 & 99.4 \\
\hline Missing & 28 & 0.6 \\
\hline
\end{tabular}

As shown in Table 3, the sample was composed of relatively equal proportions of girls and boys. In addition, most of the adolescents have mothers who completed high school (grades 9 to 12, including baccalaureate and vocational school). On average, teenagers own 6 out of 10 household goods, and most of them declare themselves to be rather religious. 
Regarding involvement in organisations with cultural, political and environmental purposes, we observe that only a small proportion of all teenagers choose to be involved in such organisations (and in all forms of NGOs; see also Table 2).

Table 3. Control and independent variables.

\begin{tabular}{|c|c|c|}
\hline Variable & Operationalization & Population Description \\
\hline \multicolumn{3}{|l|}{ Control variable } \\
\hline Gender & Dichotomy $(1$ = male $)$ & $\begin{array}{c}50.8 \% \text { male } \\
49.2 \% \text { female }\end{array}$ \\
\hline Mother's level of education & $\begin{array}{l}\text { "What was the last school your parents } \\
\text { graduated from?" } \\
\text { In the regression model: } \\
2 \text { dummy variables on the last form of } \\
\text { schooling completed by mother: } \\
\text { Education } 1 \text { ( } 1=\text { up to 8th grade) } \\
\text { Education } 2 \text { ( } 1=\text { up to high } \\
\text { school/vocational) } \\
\text { reference category: university studies; }\end{array}$ & $\begin{array}{c}24.3 \% \text {-Up to } 8 \text { grades; } \\
40.7 \% \text {-Grades } 9 \text { to } 12 \text {, including } \\
\text { baccalaureate and vocational school; } \\
10.3 \% \text {-Technical school, } \\
\text { post-secondary, college; } \\
23.3 \% \text {-University studies; } \\
1.4 \% \text {-No mother/father }\end{array}$ \\
\hline Things owned & $\begin{array}{c}\text { Summative score: scale on owning } 10 \\
\text { household items } \\
\text { Alpha }>0.07\end{array}$ & $\begin{array}{c}\text { Average }=5.98 \\
\text { Median }=6 \\
\text { Standard deviation }=2.42\end{array}$ \\
\hline Religiosity & $\begin{array}{c}\text { "Which statement below best expresses your } \\
\text { opinion of how religious you are?" } \\
\text { In the regression model: } \\
3 \text { dummy variables on the response to the } \\
\text { question of how religious one considers } \\
\text { oneself: } \\
\text { Relig1 ( } 1 \text { = I am religious in my own way) } \\
\text { Relig2 ( } 1 \text { = I am not religious) } \\
\text { Relig3 ( } 1 \text { = not religious) }\end{array}$ & $\begin{array}{c}2.6 \% \text { - I am definitely not religious, I have } \\
\text { other beliefs; } \\
6.9 \% \text { - I am not religious; } \\
48.4 \% \text { - I am religious in my own way; } \\
32 \% \text { - I am religious, I try to follow the } \\
\text { teachings of my church; } \\
10 \% \text {-Don't know whether I am religious } \\
\text { or not }\end{array}$ \\
\hline \multicolumn{3}{|l|}{ Independent variables } \\
\hline Membership in cultural organisations & dummy variable ( 1 = member) & $\begin{array}{c}2.6 \% \text { Yes } \\
3.9 \% \text { No } \\
1.1 \% \text { Don't know } \\
\text { 92.4\% Missing (answered No to the general } \\
\text { question about involvement in any kind of } \\
\text { organisation and missing) }\end{array}$ \\
\hline Membership in political organisation & dummy variable $(1=$ member $)$ & $\begin{array}{c}1.9 \% \text { Yes } \\
4.7 \% \text { No } \\
1.1 \% \text { Don't know } \\
92.3 \% \text { Missing (answered No to the general } \\
\text { question about involvement in any kind of } \\
\text { organisation and missing) }\end{array}$ \\
\hline $\begin{array}{l}\text { Membership in environmental } \\
\text { organisation }\end{array}$ & dummy variable ( 1 = member) & $\begin{array}{c}2 \% \text { Yes } \\
4.6 \% \text { No } \\
1.1 \% \text { Don't know } \\
92.4 \% \text { Missing (answered No to the general } \\
\text { question about involvement in any kind of } \\
\text { organisation and missing) }\end{array}$ \\
\hline
\end{tabular}

\subsection{Methods}

A hierarchical linear regression was used to test the three hypotheses, a method that allows the measurement of the individual effect of each variable controlling for the effect of the other variables included in the model. 
In order to test the research hypotheses, the variables were grouped into 4 nested models, as follows:

Model 1 (control variables): gender, socio-economic status (mother's education level and financial situation) and self-reported level of religiosity;

Model 2 (involvement in cultural life): membership in a cultural organisation;

Model 3 (political involvement): member of a political organisation;

Model 4 (involvement in environmental protection-sustainability): member of an environmental organisation.

\section{Results}

During the first stage of the research, preliminary analyses were carried out in order to check for multicollinearity, with the results indicating its absence.

The results indicate, as expected, the existence of significant relationships between generosity and the control variables: gender, socio-economic status and religiosity. Thus, the analyses show that girls are more generous than boys, children from families with a higher socio-economic status are more involved in acts of generosity, and children who declare themselves to be religious are more generous than those who are less religious.

As presented in Table 4, introducing the cultural activities variable into Model 2 produces a significant effect $(p \leq 0.01)$, indicating that adolescents who participate in cultural activities are more generous than those who do not participate in such activities.

Table 4. Regression model (dependent variable-generosity).

\begin{tabular}{|c|c|c|c|c|c|c|c|c|}
\hline & $\begin{array}{c}\text { Model } \\
1\end{array}$ & & $\begin{array}{c}\text { Model } \\
2\end{array}$ & & $\begin{array}{c}\text { Model } \\
3\end{array}$ & & $\begin{array}{c}\text { Model } \\
4\end{array}$ & \\
\hline Variables & Beta & Sig & Beta & Sig & Beta & Sig & Beta & Sig \\
\hline Sex & -0.173 & $0.00 * *$ & -0.175 & $0.00 * *$ & -0.176 & $0.00 * *$ & -0.176 & $0.00 * *$ \\
\hline Mother's level of education 1 & 0.092 & $0.00 * *$ & 0.093 & $0.00 * *$ & 0.093 & $0.00 * *$ & 0.092 & $0.00 * *$ \\
\hline Mother's level of education 2 & 0.058 & $0.00 * *$ & 0.061 & $0.00^{* *}$ & 0.061 & $0.00 * *$ & 0.060 & $0.00^{* *}$ \\
\hline Things owned & 0.168 & $0.00 * *$ & 0.164 & $0.00 * *$ & 0.164 & $0.00 * *$ & 0.163 & $0.00 * *$ \\
\hline Religiosity 1 & -0.089 & 0.00 ** & 0.090 & $0.00 * *$ & 0.090 & 0.00 ** & 0.090 & 0.00 ** \\
\hline Religiosity 2 & -0.147 & $0.00 * *$ & -0.145 & $0.00 * *$ & -0.145 & $0.00 * *$ & -0.146 & $0.00 * *$ \\
\hline Religiosity 3 & -0.108 & $0.00 * *$ & -0.104 & $0.00 * *$ & -0.104 & $0.00 * *$ & -0.105 & $0.00 * *$ \\
\hline Cultural organisation member & & & 0.046 & $0.00 * *$ & 0.043 & $0.02 *$ & 0.021 & 0.326 \\
\hline Political organisation member & & & & & 0.007 & 0.366 & -0.007 & 0.736 \\
\hline $\begin{array}{l}\text { Member of environmental } \\
\text { protection organisation }\end{array}$ & & & & & & & 0.048 & 0.027 * \\
\hline
\end{tabular}

${ }^{*} p<0.05,{ }^{* *} p<0.01$

In Model 3, the newly introduced variable specific to political activism has no effect on generosity. However, we observe that the significant effect $(p \leq 0.05)$ between membership of a cultural organisation and generosity is maintained, but this relationship does not hold when we introduce the variable concerning membership of an organisation for the protection of the environment.

For Model 4, membership in an environmental organisation produces a significant effect $(p \leq 0.05)$, indicating that adolescents who are concerned about protecting the environment have a higher level of generosity than those who are not involved in such environmental organisations.

The controls introduced in the first block-gender, socio-economic status and level of religiosity - explain $8.7 \%$ of the total variance in generosity. The specific variable of belonging to an organisation that focuses on cultural or environmental protection activities improves the model very slightly, so that the model finally explains $8.9 \%$ of the total 
variances (see Table 5); this model is statistically significant according to ANOVA results (see Table 6).

Table 5. Model summary (dependent variable—generosity).

\begin{tabular}{cccc}
\hline Model & R Square & Adjusted R Square & Standard Error \\
\hline 1 & 0.089 & 0.087 & 0.955 \\
\hline 2 & 0.091 & 0.089 & 0.954 \\
\hline 3 & 0.091 & 0.088 & 0.954 \\
\hline 4 & 0.092 & 0.089 & 0.954 \\
\hline
\end{tabular}

Table 6. ANOVA (dependent variable-generosity).

\begin{tabular}{ccc}
\hline Model & F & Sig. \\
\hline 1 & 46.994 & 0.000 \\
\hline 2 & 42.166 & 0.000 \\
\hline 3 & 37.486 & 0.000 \\
\hline 4 & 34.266 & 0.000 \\
\hline
\end{tabular}

\section{Discussion}

The present research was based on three hypotheses concerning the relationship between generosity and involvement in cultural, political and environmental NGOs, with the latter being the central objective of the research. We began by identifying the level of involvement of adolescents in non-governmental organisations. Analyses show that adolescents in Romania are still not very involved in volunteering activities, being active in non-governmental organisations only in very small numbers. Thus, less than $10 \%$ of the 4333 respondents said they are members of an NGO. Similar results were found among another sample of young Romanians conducted by Bădescu et al. [54] in 2017-2018, where about $12 \%$ of respondents (aged 15-29) said they had volunteered in the past year, as opposed to about $30 \%$ of Europeans on average. One explanation for this low rate can be the fact that young Romanian people do not consider volunteering as important in finding a job. According to the same survey, the most important aspects in finding a job are considered to be the person's level of education, luck, acquaintances and good connections. Most declare that volunteering activities were done through school or college. This highlights the lack of adequate educational programmes to support this kind of behaviour. It also emphasizes the potential for increasing involvement in volunteering activities through educational programmes.

Regarding the first hypothesis, the results of the study show a significant relationship between adolescents' self-reported generosity and being a member in a cultural organisation. These results are visible even when controlling for the effect of gender differences, socio-economic status or religiosity. Thus, adolescents that have internalized values regarding voluntary involvement in cultural activities will also embrace values regarding concern for the wellbeing of those in need. Adolescents who are members of an organisation are more generous than those who are not involved in cultural organisations. According to other studies, cultural experiences appear to contribute to the development of pro-social behaviours in general and, by extension, of generosity [55].

The relationship between generosity and involvement in organisations with a political purpose was tested throughout the second hypothesis. However, the results do not support the hypothesis, and as such, we cannot speak to this relationship. Young Romanians engage very little in politics, and the level of education and religiosity are two important predictors of this. Thus, the less religious and those with a higher educational level are more open to politics [54]. On the other hand, generosity correlates positively with religiosity and 
education level, and this might explain to some extent the lack of a relationship between involvement in political NGOs and generosity.

In the last model of the regression, the relationship between generosity and sustainability was tested, which was the main purpose of the present research; the introduction of the variables related to political and cultural involvement in models 2 and 3 was a preliminary step in order to determine the relationship between generosity and sustainability, under the condition that the effect of the variables related to political and cultural activities is controlled (as well as the effect of the control variables). Thus, the third hypothesis of the study is confirmed: sustainable attitudes and practices, operationalized by involvement in environmental organisations, correlate strongly with high levels of generosity. Adolescents concerned about protecting the environment appear to have also internalized values related to helping others. The results are consistent with the results of other studies, of which there are still very few in this area [47-50]. A recent study shows a strong correlation between pro-social behaviour and pro-environmental behaviour, suggesting that "prosocial and pro-environmental behaviours are actually more connected than one might initially think" [47]. In the same study, by analysing scales designed to operationalise pro-social and pro-environmental behaviours, the authors conclude that the two types of scales could be combined, having a good reliability, pointing out that the two types of behaviours could be part of a common class. It seems that not only environmental protection behaviours, but also the simple presence of people in nature, is correlated with generosity. Piff et al. [56] demonstrated that by simply admiring eucalyptus trees for a minute makes people more willing to pick up a researcher's "accidentally" knocked over pens, as opposed to those who looked at a building for the equivalent time. Taken as a whole, most pro-environmental behaviour is based on a general pro-social attitude, and the behaviour directed towards that area depends partly on the individual's attachment to that specific area: "prosocial behavior inherently stems from a connection to the relevant domain-in this case, the ecological domain" [51].

On the other hand, although in the second model a significant relationship is observed, in the last block, the effect of the variable concerning the involvement in a cultural organisation becomes non-significant when adding the variable referring to activism in an environmental organisation.

The finding that the effect of the cultural activities variable on generosity is no longer maintained in the last block indicates that sustainability concerns are a stronger predictor of generosity and caring values than cultural attitudes and interests or a third variable, be it a latent one, explaining both relationships with measures of self-reported generosity. The present study has some limits that need to be taken into consideration. First of all, one limitation is the level of desirability of the respondents, in particular the answers given in terms of generosity, but also in terms of the degree of involvement in cultural, political or pro-environmental organisations. In addition, the operationalisation of generosity as an attitude and not through observable behaviours may be a possible limiting factor, as reliability is a concern in this case, although this operationalisation is common in other studies. The generosity scale used in the present study may also generate desirable responses because the items are formulated in a positive manner, although this type of response is encountered in other studies [4,27,57]. On the other hand, there are no scales for operationalizing generosity that are generally recognized and endorsed for psychometric properties in the literature; in fact, there is a general lack of instruments to measure generosity.

Equally important is the limitation that operationalising sustainability practices and interests only through involvement in pro-environmental organisations could be considered reductionist. Last but not least, the sample, although quite large, only covers the schoolgoing population (youth aged 14/15) in Bihor County, Romania. 


\section{Conclusions}

The present study was carried out in order to answer the question of whether there is a potential correlation between generosity - as a positive attitude towards others-and sustainability practices_as a positive attitude towards the environment.

Similar to other research findings, the results of the analyses carried out in this study confirmed our expectations and indicated the existence of a significant relationship between the two positive attitudes, already noticeable during adolescence. Contrary to what was expected, generosity is not significantly correlated with involvement in cultural organisations or involvement in political organisations when controlling for membership in environmental organisations. This suggests a latent factor that lies behind membership in NGOs and also explains the correlation of generosity with environmental interests and practices.

Our results lead us to consider sustainability as a form of giving that contributes to the collective good, which involves giving up a resource, similar to [27]. People who pay more money for resources that cause less harm to the environment or have less environmental impact than other resources incur a personal cost that contributes to public welfare. Such people may end up having less money available to give to charitable causes as a result of this form of giving. In conclusion, the need for charitable causes to repair the damage caused by harmful consumption customs may decrease if this form of generosity is more widely practiced. From a theoretical point of view, generosity and environmental concerns are both facets of a probably larger pro-social axiological structure.

Our recommended courses of action include raising social-human values, developing a set of skills that entail individual and community practices, shaping attitudes (see Bloom's taxonomy; see new environmental education, Europe 2020 strategy) and applied educational and environmental policies.

We set out to answer the question of how teachers can support youth in becoming generous and environmentally aware in order to support a sustainable future through their conduct. In order to be successful, the developed principles and practices for sustainable education would need to have a flexible and adaptable nature, implying a resilient and a healthy education delivery system, continuously adapting to structural and situational constraints as well as to existing regulations. This requires a consideration of three important factors: behavioural research (which involves an analysis for the impact of knowledge, information and education on behavioural change), sustainability competencies (analysis of competencies such as integrative thinking and an understanding of interconnection) and educational pedagogy (anticipatory thinking; involvement and collaboration of stakeholders, action orientation skills and the agency of change) and how can they be effectively addressed in the learning pathway [57].

In this respect, we can highlight a set of proposals for a curriculum policy aiming to cultivate global civic generosity in students by/through its guidelines: enhancing collective local and global partnership to entail generosity, diverse cultural and philosophical views for the understanding of generosity; intergenerational story sharing as celebrating generosity; ecological representations of this virtue for the analysis of generosity; and creating and presenting children's stories in a public library as a civic participation of generosity [52].

All of us have an ethical responsibility to promote national provisions to enable children to understand and commit to sustainability, as well as peaceful, creative and collaborative strategies to address these looming challenges [58].

The paramount role of young people in tackling environmental issues is stressed from the very beginning of their lives, along with what is, according to the above, the importance of developing a moral and civic attitude through axiological education, together with the development of a consistent conduct, measurable by good practices and skills. We note the high importance of getting children involved in environmental issues from the very beginning of their lives and, as mentioned above, the importance of building a morally civic attitude, instilled through axiological education as well as the development of value-conscious behaviours measured by good practices and skills. 
A new technological advancement may facilitate people to become able to give in more ways than they have done in the past. Following this, the expression of generosity, in more ways, may be a phenomenon that we can expect to become increasingly common among givers, requiring researchers to broaden the field of application of these insights (see also [27]).

Values such as sustainability and caring for our surroundings are responses to the challenges of today's world. Given that values as cultural constructs are subject to change and influenced by cultural-historical dynamics, we are facing a new cultural reality, wherein a primary goal is to equip the new generations for living and for acting in a sustainable way.

Author Contributions: Conceptualization, C.B., I.S. and K.B.; methodology, A.L. and A.H.; writingoriginal draft preparation, C.B., I.S., K.B. and A.L.; writing-review and editing, C.B., I.S., K.B., A.H. and A.L. All the authors have contributed equally to this work and share first authorship. All authors have read and agreed to the published version of the manuscript.

Funding: This research received no external funding.

Institutional Review Board Statement: We have a collaboration protocol between institutions. University of Oradea and the School Inspectorate. Student participation was voluntary and anonymous.

Informed Consent Statement: Informed consent was obtained from all subjects involved in the study.

Conflicts of Interest: The authors declare no conflict of interest.

\section{References}

1. Sharma, M. A value approach to sustainable development. In Environmental Protection and Sustainable Development; Anamika Publishers: New Delhi, India, 2015; pp. 181-186.

2. Huckle, J.; Sterling, S.R. Education for Sustainability; Earthscan: London, UK, 1996.

3. Cristea, S.J. Educaţia prin şi pentru valori. Rev. Didact. Pro. Rev. Teor. Pract. Educ. 2006, 35, 56-58.

4. Brown, M. The power of generosity to change views on social power. J. Exp. Soc. Psychol. 2011, 47, 1285-1290. [CrossRef]

5. Diamond, J. Collapse: How Societies Choose to Fail or Succeed; Penguin: New York, NY, USA, 2011.

6. Gerlagh, R.; Vollebersh, H. Sustainability as generosity. Earth Environ. Sci. 2009, 6, 1-3. [CrossRef]

7. Bartlett, A.A. The meaning of sustainability. Teach. Clgh. Sci. 2012, 31, 1-14.

8. Johansson, E. The preschool child of today-The world-citizen of tomorrow? Int. J. Early Child. 2009, 41, 79-95. [CrossRef]

9. United Nations Educational, Scientific and Cultural Organization (UNESCO). Global Education Monitoring Report 2019: Migration, Displacement and Education: Building Bridges, Not Walls. 2019. Available online: https://unesdoc.unesco.org/ark: /48223/pf0000265866 (accessed on 29 July 2021).

10. Bell, W. Foundations of Futures Studies: Human Science for a New Era: Values, Objectivity, and the Good Society; Transaction Publishers: Piscataway, NJ, USA, 2011; Volume 2.

11. Hart, D.; Atkins, R.J. Civic competence in urban youth. Appl. Dev. Sci. 2002, 6, 227-236. [CrossRef]

12. Kohlberg, L. Essays on Moral Development/2 The Psychology of Moral Development; Harper \& Row: New York, NY, USA, 1984.

13. Onaga, F.; Bălău, C.; Neagoe, A. Studiu comparativ privind influența educației moral-creștine în prevenirea comportamentelor deviante la elevii de liceu. Acta Univ. Georg. Bacovia 2019, 8, 89-114.

14. Davis, J. Young children, environmental education and the future. Early Child. Educ. J. 1998, 2, 141-155.

15. Mandel, P. Children as Change Agents: The Influence of Integrating Environmental Education into Home Learning Projects on Families and Community Members. 2013. Available online: https://digitalcommons.fiu.edu/cgi/viewcontent.cgi?article=1098 \&context=sferc (accessed on 4 August 2021).

16. Uitto, A.; Boeve-de Pauw, J.; Saloranta, S. Participatory school experiences as facilitators for adolescents' ecological behavior. J. Environ. Psychol. 2015, 43, 55-65. [CrossRef]

17. Dewey, J. Experience and education. In Proceedins of The Educational Forum; Springer: New York, NY, USA, 1986; pp. $241-252$.

18. Schugurensky, D.; Myers, J. Citizenship education: Theorys, research and practice. Encount. Theory Hist. Educ. 2003, 4, 1-10. [CrossRef]

19. Brooks, R.M.; Holford, J.A. Citizenship, learning and education: Themes and issues. Citizsh. Stud. 2009, 13, 85-103. [CrossRef]

20. Tschentscher, T. Promoting Sustainable Development through More Effective Civil Society Participation in Environmental Governance. 2016. Available online: https:/ / ec.europa.eu/environment/international_issues/pdf/EU_NGOs_publication_20 161219.pdf (accessed on 27 July 2021).

21. Dupuits, E. Actors other than States: The Role of Civil Society and NGOs as Drivers of Change. Environ. Clim. Change Int. Relat. 2016, 114-131.

22. Sawhney, P.; Kobayashi, M.; Takahashi, M.; King, P.; Mori, H. Participation of civil society in management of natural resources. Int. Rev. Environ. Strateg. 2007, 7, 117-132. 
23. Civil Society Participation in the Implementation of Agenda 2030 on Sustainable Development. Report to the Special Rapporteur on the Rights to Freedom of Peaceful Assembly and of Association. 2019. Available online: https://europa.eu (accessed on 4 August 2021).

24. The United Nations Environment Programme (UNEP). 2016. Available online: https://environmentlive.unep.org/media/docs/ assessments/UNEP_Frontiers_2016_report_emerging_issues_of_environmental_concern.pdf (accessed on 27 July 2021).

25. Unicef. Building the Future: Children and the Sustainable Development Goals in Rich Countries. 2017. Available online: https:/ / www.unicef-irc.org/publications / 890-building-the-future-children-and-the-sustainable-development-goals-inrich-countries.html (accessed on 17 November 2021).

26. The United Nations Environment Programme (UNEP). 2018. Available online: https://www.unep.org/resources/unenvironment-2018-annual-report (accessed on 17 November 2021).

27. Herzog, P.S.; Price, H.E. American Generosity: Who Gives and Why; Oxford University Press: Oxford, UK, 2016.

28. Safra, L.; Tecu, T.; Lambert, S.; Sheskin, M.; Baumard, N.; Chevallier, C. Neighborhood deprivation negatively impacts children's prosocial behavior. Front. Psychol. 2016, 7, 1760. [CrossRef]

29. Deary, I.J.; Der, G.; Ford, G.J.I. Reaction times and intelligence differences: A population-based cohort study. Intelligence 2001, 29, 389-399. [CrossRef]

30. Son, J.; Wilson, J. Education, perceived control, and volunteering. Sociol. Forum. 2017, 32, 831-849. [CrossRef]

31. Wiepking, P.; Maas, I.J. Resources that make you generous: Effects of social and human resources on charitable giving. Soc. Forces 2009, 87, 1973-1995. [CrossRef]

32. Hauge, K.E. Generosity and guilt: The role of beliefs and moral standards of others. J. Econ. Psychol. 2016, 54, 35-43. [CrossRef]

33. Wiepking, P.; Bekkers, R. Who gives? A literature review of predictors of charitable giving. Part Two: Gender, family composition and income. Volunt. Sect. Rev. 2012, 3, 217-245. [CrossRef]

34. Black, J.F.; Davidai, S. Do rich people "deserve" to be rich? Charitable giving, internal attributions of wealth, and judgments of economic deservingness. J. Exp. Soc. Psychol. 2020, 90, 104011. [CrossRef]

35. Einolf, C.J. Gender differences in the correlates of volunteering and charitable giving. Nonprofit Volunt. Sect. Q. 2011, 40, 1092-1112. [CrossRef]

36. Lazăr, A.; Hatos, A. Generosity and Prosocial Behavior in Middle School. The Results of a Survey in Bihor County Schools. Emerging Markets Economics Business. Contributions of Young Researchers. Oradea, Romania. 2016. Available online: http:/ /steconomiceuoradea.ro/wp/wp-content/uploads/2014/01/volum_final-2016.pdf (accessed on 3 November 2021).

37. Lazăr, A.; Hatos, A. Religiosity and Generosity of Youth. The Results of a Survey with 8th Grade Students from Bihor County (Romania). Rev. Rom. Pentru Educ. Multidimens.-J. Multidimens. Educ. 2019, 11, 93-118. [CrossRef]

38. Willer, R.; Wimer, C.; Owens, L.A. What drives the gender gap in charitable giving? Lower empathy leads men to give less to poverty relief. Soc. Sci. Res. 2015, 52, 83-98. [CrossRef]

39. Cox, J.C.; Deck, C.A. When are women more generous than men? Econ. Inq. 2006, 44, 587-598. [CrossRef]

40. Bekkers, R.H.F.P. Giving and Volunteering in The Netherlands: Sociological and Psychological Perspectives; Utrecht University: Utrecht, The Netherlands, 2004.

41. Bekkers, R.; Wiepking, P. Who gives? A literature review of predictors of charitable giving part one: Religion, education, age and socialisation. Volunt. Sect. Rev. 2011, 2, 337-365. [CrossRef]

42. Eckel, C.C.; Grossman, P.J. Rebate versus matching: Does how we subsidize charitable contributions matter? J. Public Econ. 2003, 87, 681-701. [CrossRef]

43. Lim, C.; MacGregor, C.A. Religion and volunteering in context: Disentangling the contextual effects of religion on voluntary behavior. Am. Sociol. Rev. 2012, 77, 747-779. [CrossRef]

44. Ruiter, S.; De Graaf, N.D. National context, religiosity, and volunteering: Results from 53 countries. Am. Sociol. Rev. 2006, 71, 191-210. [CrossRef]

45. Kasser, T. Frugality, generosity, and materialism in children and adolescents. In What Do Children Need to Flourish? Springer: Berlin/Heidelberg, Germany, 2005; pp. 357-373.

46. Neaman, A.; Otto, S.; Vinokur, E.J.S. Toward an integrated approach to environmental and prosocial education. Sustainability 2018, 10, 583. [CrossRef]

47. Schultz, P.W.; Gouveia, V.V.; Cameron, L.D.; Tankha, G.; Schmuck, P.; Franěk, M. Values and their relationship to environmental concern and conservation behavior. J. Cross-Cult. Psychol. 2005, 36, 457-475. [CrossRef]

48. Stern, P. Toward a coherent theory of environmentally significant behavior. Envtl. Law Rep. News Anal. 2000, 56, 407-424.

49. Stern, P.C.; Dietz, T.J. The value basis of environmental concern. J. Soc. Issues 1994, 50, 65-84. [CrossRef]

50. Otto, S.; Pensini, P.; Zabel, S.; Diaz-Siefer, P.; Burnham, E.; Navarro-Villarroel, C.; Neaman, A. The prosocial origin of sustainable behavior: A case study in the ecological domain. Glob. Environ. Change 2021, 69, 102312. [CrossRef]

51. Liu, L.B. Cultivating Civic Generosity in Elementary Youth Across Glocal Cultures, Ecologies, and Generations. In Civic Engagement and Politics: Concepts, Methodologies, Tools, and Applications; IGI Global: Pennsylvania, PA, USA, 2019 ; pp. 809-823.

52. Hatos, A. Scala de Generozitate a Adolescenților. Dezvoltare și Unele Proprietăți. 2020. Available online: https://www. researchgate.net/profile/Adrian-Hatos/publication/346059077_Scala_de_generozitate_a_adolescentilor_Dezvoltare_si_ unele_proprietati/links/5fb92fc3458515b7975cbddb/Scala-de-generozitate-a-adolescentilor-Dezvoltare-si-unele-proprietati. pdf (accessed on 4 November 2021). 
53. Bădescu, G.; Sandu, D.; Angi, D.; Greab, C. Studiu Despre Tinerii din România 2018-2019 (Research on Young People in Romania 2018-2019); Friedrich Ebert Stiftung: Bonn, Germany, 2019.

54. Martin, D.; Martin, M.; Gibson, S.S.; Wilkins, J.J.A. Increasing prosocial behavior and academic achievement among adolescent African American males. Adolescence 2007, 42, 689-699.

55. Piff, P.K.; Dietze, P.; Feinberg, M.; Stancato, D.M.; Keltner, D. Awe, the small self, and prosocial behavior. J. Personal. Soc. Psychol. 2015, 108, 883. [CrossRef]

56. Buhrow, W.; Bufford, R.K.; Webb, K.C. Preliminary Validation of a Measure of Generosity. In Proceedings of the Faculty Publications-Doctor of Psychology (PsyD) Program; 2010. Paper 22. Available online: https:/ / digitalcommons.georgefox.edu/ cgi/viewcontent.cgi? article $=1021 \&$ context=gscp_fac (accessed on 7 December 2021).

57. Frisk, E.; Larson, K.L.J. Educating for sustainability: Competencies \& practices for transformative action. J. Sustain. Educ. 2011, 2, $1-20$.

58. Ritchie, J. Sustainability and relationality within early childhood care and education settings in Aotearoa New Zealand. Int. J. Early Child. 2013, 45, 307-326. [CrossRef] 